\title{
Hak dan Kewajiban Pola Hidup Sehat Melalui Food Combining Di Ranah Komunikasi \\ Kesehatan
}

\author{
DEVRITA AYU PUTRI DESTIAWAN \\ IIK STRADA INDONESIA ( S1 FARMASI ) \\ devritaayu1@gmail.com
}

\begin{abstract}
ABSTRAK
Gaya hidup sehat merupakan gaya hidup ideal bagi setiap orang dan merupakan upaya untuk mencapai tujuan tersebut. Berbagai hal dilakukan oleh masyarakat, misalnya mengatur pola makan sesuai kebutuhan tubuh dengan campuran karbohidrat, protein, dan unsur lainnya memerlukan teknik certoin yang dapat dicerna dengan keseimbangan komposisi yang ada di Food Combining adalah salah satu caranya. untuk mencapai gaya hidup sehat melalui diet sehat. Dimana inti dari food kombinasi adalah makanan segar dan tidak alami, mengkonsumsi makanan kombinasi dengan mengikuti siklus metabolisme, menjaga keseimbangan asam basa tubuh, dan tidak perlu mengukur konsumsi makanan. Model Kepercayaan (Health Belief Model) dikemukakan oleh Rosenstock pada tahun 1974 yang memiliki konsep bahwa perilaku seseorang yang dapat memberikan penilaian dan penjabaran kesehatan sosial-psikologis. Dengan demikian, peningkatan pengetahuan dan sikap tentang kerentanan dan kemanjuran pengobatan dapat mempengaruhi keputusan seseorang tentang perilaku kesehatan. Selanjutnya, pendekatan analitis dalam literatur dengan mengumpulkan sejumlah jurnal atau publikasi lain yang terkait dengan masalah yang diteliti serta pengungkapan relevansi teori dan masalah yang dibahas. Dengan pendekatan Health Belief Model diharapkan keyakinan terhadap masalah kesehatan tertentu, efektif dalam mengobati dan mencegah penyakit, dapat mengubah kebiasaan buruk masyarakat dalam mengobati penyakit, dan dapat menerima saran untuk melakukan tindakan kesehatan.
\end{abstract}

\section{Kunci : Food Combining Kata,Health Belief Model,Gaya Hidup Sehat}

\section{A. LATAR BELAKANG}

Setiap makhluk hidup di dunia ini akan memiliki kehidupan sesuai dengan rantai kehidupan yang telah digariskan oleh Sang Maha Pencipta. Sehingga segala hal yang akan 
dilalui dalam masa kehidupannya akan berjalan secara teratur dan tidak akan memiliki ketidakteraturan didalam rantai kehidupannya. Salah satu makhluk ciptaan-Nya adalah kita sebagai manusia yang memiliki keteraturan hidup yang sempurna karena memiliki kelebihan dibandingkan makhluk ciptaan lainnya. Manusia diciptakan memiliki raga, jiwa, dan ruh yang harus dipelihara secara keseluruhan karena ketiga hal tersebut saling terkait antara satu dengan yang lainnya. Sekedar mengingatkan pepatah yang mengatakan bahwa "didalam tubuh yang sehat terdapat jiwa yang kuat" dimana maknanya adalah tubuh yang sehat akan menghasilkan tindakan dan pemikiran yang positif dan sehat yang akan berdampak pada terbentuknya lingkungan yang kondusif bagi diri sendiri, keluarga, lingkungan sekitar, dan masyarakat. Untuk mendapatkan tubuh yang sehat maka diperlukannya beberapa upaya yang perlu kita lakukan agar dapat menghasilkan pola hidup sehat bagi diri kita sendiri. Ada berbagai cara dan upaya yang dapat kita lakukan dalam menghasilkan pola hidup sehat yaitu melalui olahraga, menjaga keseimbangan pola makan teratur, diet sehat, detoks tubuh, dan lainnya. Diet sehat merupakan salah satu teknik mengatur pola makan yang cukup favorit dibeberapa negara dan banyak dilakukan oleh berbagai kalangan. Salah satunya tekniknya dinamai Food Combining yang dipopulerkan di Indonesia oleh Andang Gunawan melalui buku yang ditulis beliau pada tahun 1999.

\section{B. KASUS/MASALAH}

Gangguan metabolisme tubuh terjadi jika pola makan tidak sesuai dengan cara kerja sistem pencernaan. Jika kita melakukan program diet yang cukup banyak dengan memaksa pencernaan menyesuaikan dengan aturan yang kita lakukan, maka diet food combining terjadi sebaliknya. Diet food combining menawarkan pola makan yang sudah sesuai dengan kerja alami sistem pencernaan.

Adapun tujuan metode Food Combining adalah mengurangi timbunan lemak dan toksik

(menurunkan berat badan) serta mencegah gangguan pencernaan

(http:izzatunnisa.wordpress.com). Pada saat munculnya metode ini maka muncul perpindahan kebiasaan masyarakat yang mulanya sangat bergantung dengan obatobatan medis lalu mencoba untuk mengkonsumsi makanan yang bersifat alami (herbal) yang dapat membantu penyembuhan penyakit yang diterima. 


\section{TINJAUAN PUSTAKA}

Teori ini merupakan teori umum yang biasa digunakan dalam pendidikan kesehatan dan promosi kesehatan dimana hal ini sejalan dengan makna secara umum dari komunikasi kesehatan yaitu omunikasi kesehatan yaitu proses penyampaian pesan kesehatan oleh komunikator melalui saluran atau media tertentu pada komunikan dengan tujuan untuk mendorong perilaku manusia tercapainya kesejahteraan sebagai kekuatan yang mengarah kepada keadaan (status) sehat utuh secara fisik, mental (rohani) dan sosial.

Komunikasi kesehatan lebih sempit daripada komunikasi manusia pada umumnya. Komunikasi kesehatan berkaitan erat dengan bagaimana individu dalam masyarakat berupaya menjaga kesehatannya yang terkait dengan berbagai isu yang berhubungan dengan kesehatan. Dalam komunikasi kesehatan, fokusnya meliputi transaksi hubungan kesehatan secara spesifik, termasuk berbagai faktor yang ikut berpengaruh terhadap transaksi yang dimaksud. Dalam tingkat komunikasi, komunikasi kesehatan merujuk pada bidang - bidang seperti program - program kesehatan nasional dan dunia, promosi kesehatan, dan rencana kesehatan publik. Health Belief Model memiliki pengertian yaitu sebuah bentuk perilaku dimana seseorang memberikan penilaian dan penjabaran terhadap kesehatan dari segi sosiopsikologis. Sedangkan perilaku adalah respon individu terhadap suatu stimulus atau suatu tindakan yang dapat diamati dan mempunyai frekuensi spesifik, durasi dan tujuan baik disadari maupun tidak. Perilaku merupakan kumpulan berbagai faktor yang saling berinteraksi. Sering tidak disadari bahwa interaksi tersebut amat kompleks sehingga kadangkadang seseorang tidak sempat memikirkan penyebab menerapkan perilaku tertentu (dalam Notoatmodjo, 2003).

\section{PEMBAHASAN}

Pembahasan mengenai food combining sebagai pesan efektif dalam menghasilkan gaya hidup sehat ditinjau dari model kepercayaan kesehatan (HBM) didasarkan pada tiga faktor esensial yaitu seseorang mau mengubah perilaku untuk memperkecil resiko kesehatan atau menghindari suatu penyakit melalui pesan yang disampaikan, memiliki dorongan dari lingkungan eksternal yang mampu membuat dirinya mengubah perilaku yang telah ada, dan perilaku individu yang disesuaikan dengan karakter diri sendiri atau penilaian diri pribadi atau pengalaman untuk mencoba mengubah perilaku yang serupa. Maka untuk menganalisis food combining sebagai 
pesan yang efektif dalam menghasilkan gaya hidup sehat maka difokuskan pada kerentanan, keseriusan, hambatan, keuntungan, self eficacy dan cues to action.

\section{Kerentanan (Perceived Susceptibility)}

Pada kondisi ini seseorang akan bisa merasakan kondisi badan jika terkena suatu penyakit yang dapat membahayakan kondisi badannya. Apabila salah untuk mengkonsumsi suatu makanan tertentu maka akan dapat memprediksikan hal apa yang akan terjadi pada dirinya sehingga dirinya mamppu untuk melakukan penilaian terhadap resiko yang akan dihadapi jika mendapatkan kondisi badan yang tidak nyaman. Selain itu informasi yang diperoleh dapat melalui media massa untuk dapat memahami apa yang bisa prediksi jika seseorang terkena suatu penyakit tertentu yang rentan terhadap suatu kondisi tertentu. Tingkat kerentanan pun dapat diketahui melalui informasi secara online yang dapat dicontohkan jika seseorang mengkonsumsi daging merah terlalu banyak ditambah dengan makanan pendamping yang dapat memicu penyakit hipertensi atau kolesterol maka akan mendapatkan penyakit hipertensi, kolesterol, dan lainnya. Maka dapat melakukan penilaian diri apakah tingkat keparahan dapat membahayakan atau tidak atas suatu penyakit seperti yang diterangkan dalam konstruk Health Belief Model.

\section{E. KESIMPULAN}

Melalui pembahasan diatas bahwa untuk meningkatkan kepercayaan diri dalam melakukan pengobatan secara non-medis dapat ditumbuhkembangkan melalui diri sendiri dengan berbagai tahapan yang harus dilalui dengan beberapa rangkaian langkah yaitu: kerentanan, keseriusan, hambatan, keuntungan, self eficiacy, dan cues to action.

\section{F. DAFTAR PUSTAKA}

Arikunto, Suharsimi. 2007. Prosedur

Penelitian. Rineka Cipta

Becker, Marshall H. 1984. "The Health Belief Model: A Decade Later". Health Education Quarterly, Spring.

Glanz, K., Marcus Lewis, F. \& Rimer, B.K. 1997. Theory at a Glance: A Guide for

\section{Health Promotion}

Practice. National Institute of Health.

Maulana, Heri DJ. 2009. Promosi Kesehatan.

Surabaya: EGC 
Mukhtar. 2013. Metode Praktis Deskriptif Kualitatif. Jakarta: GP Press Group.

Notoatmodjo, Soekidjo. 2003. Pendidikan Dan Perilaku Kesehatan. Rineka Cipta. Jakarta. Website: $\quad$ http://health.detik.com

http://www.gramediapustakautama.com

Tule, A. R., Siyoto, S., Dwianggimawati, M. S., \& Sodik, M. A. (2018). The Analysis Factors Affecting Interest In Medication Of Receipt Help Aid Bpjs Participant In Balowerti Public Health Center Kediri City.Journal of Global Research in Publi c Health,3(1), 68-75.Undang-undang Nomor 24 Tahun 2011 Tentang Badan Penyelenggaraan Jaminan Sosial (BPJS) Kesehatan, di download. 25 september 2017.

WP, Q. L. S., Sodiq, M. A., \& Indonesia, I. S. K. Bahaya Merokok dan Pengaruh Bagi Kesehatan. 